\title{
EXTENSÃO UNIVERSITÁRIA ACADÊMICA, PROCESSUAL E ORGÂNICA: UM PROJETO DE FORMAÇÃO DE PROFESSORES
}

\author{
Andréa Kochhann ${ }^{1,}$ Maria Eneida da Silva ${ }^{2,}$ Maria Cecília Silva de
}

AMORIM $^{3}$

Resumo: A extensão universitária brasileira tem influências europeia e norte americana na constituição da concepção de atividades extensionistas. Por muitos anos a concepção foi de prestação de serviços e assistencialismo. Nos últimos anos a concepção começa a dar sinais de mudanças, caminhando para a constituição da concepção acadêmica, com característica processual e orgânica. A discussão sobre a extensão acadêmica, processual e orgânica ainda está em processo de compreensão e pouco presente no cenário de debates e pesquisas. É objetivo deste artigo apresentar uma experiência de projeto de extensão pela concepção acadêmica, processual e orgânica, realizada pelo GEFOPI - Grupo de Estudos em Formação de Professores e Interdisciplinaridade, da Universidade Estadual de Goiás. O projeto de extensão é o ENFORMA - Encontro de Formação de Professores, cujo objetivo é a formação inicial e continuada de acadêmicos e professores. Em 2017, foram realizados três encontros e em 2018, objetivam-se oito.

Palavras-chave: Extensão Acadêmica, Processual e Orgânica. ENFORMA.

1 Pedagoga (UEG; Especialista em Docência Universitária (UEG); Mestra em Educação (PUC/GO); Doutoranda em Educação (UnB). Docente da UEG, Coordenadora do GEFOPI - Grupo de Estudos em Formação de Professores e Interdisciplinaridade. andreakochhann@yahoo.com.br

2 Mestra em Educação, Linguagem e Tecnologias pela Universidade Estadual de Goiás (UEG); Especialista em Língua Inglesa (UniEvangélica/GO); Graduada em Letras Português/Inglês (UEG). Docente titular da UEG, diretora do Campus Luziânia da UEG, pesquisadora do GECG - Grupo de Pesquisa em Educação, Gestão e Cultura Regional e membro do GEFOPI - Grupo de Estudos em Formação de Professores e Interdisciplinaridade. eneida.silva@ueg.br

3 Pedagoga e especialista em Psicopedagogia pela Universidade Estadual de Goiás Câmpus Luziânia, especializanda em Arte-Educação Intermidiática Digital pela UFG, membro do GEFOPI - Grupo de Estudos em Formação de Professores e Interdisciplinaridade, professora da rede municipal de Luziânia.cissa24@gmail.com 


\title{
UNIVERSITY ACADEMIC, PROCEDURAL AND ORGANIC EXTEN- SION: A TEACHER FORMATION PROJECT
}

\begin{abstract}
The Brazilian university extension has European and North American influences in the constitution of extensionist activities. For many years the conception was of providing services and assistance. In the last years the conception begins to show signs of change, moving towards the constitution of the academic conception, with procedural and organic characteristics. The discussion about academic, procedural and organic extension is still in the process of understanding and little present in the debates and research scenario. The objective of this article is to present an extension project experience for the academic, procedural and organic conception carried out by GEFOPI - Group of Studies in Teacher Training and Interdisciplinarity, of the State University of Goiás. The extension project is ENFORMA - Training Meeting of Teachers, whose objective is the initial and continued formation of academics and teachers. In 2017, three meetings were done and in 2018 eight meetings will be done.
\end{abstract}

Key words: Academic, Procedural and Organic Extension. ENFORMA

\section{EXTENSIÓN UNIVERSITARIA ACADÉMICA, PROCESAL Y ORGÁNI- CA: UN PROYECTO DE FORMACIÓN DE PROFESORES}

Resumen: La extensión universitaria brasileña tiene influencias europea y norteamericana en la constitución de la concepción de actividades extensionistas. Por muchos años la concepción fue de prestación de servicios y asistencialismo. En los últimos años la concepción empieza a dar señales de cambios, caminando hacia la constitución de la concepción académica, con característica procesal y orgánica. La discusión sobre la extensión académica, procesal y orgánica aún está en proceso de comprensión y poco presente en el escenario de debates e investigaciones. El objetivo de este artículo presenta una experiencia de proyecto de extensión por la concepción académica, procesal y orgánica, realizada por el GEFOPI - Grupo de Estudios en Formación de Profesores e Interdisciplinariedad, de la Universidad Estatal de Goiás. El proyecto de extensión es el ENFORMA - Encuentro de Formación de Profesores, cuyo objetivo es la formación inicial y continuada de académicos y profesores. En 2017, se realizaron tres encuentros y en 2018, se objetivan ocho.

Palabras clave: Extensión Académica, Procesal y Orgánica. ENFORMA. 


\section{INTRODUÇÃO}

Este artigo objetiva apresentar uma experiência de projeto de extensão pela concepção acadêmica, processual e orgânica, realizada pelo GEFOPI Grupo de Estudos em Formação de Professores e Interdisciplinaridade, da UEG - Universidade Estadual de Goiás. O GEFOPI é registrado como um projeto de extensão, mas tem características de um programa ou projeto integrado, pois abrange várias atividades do ensino, da pesquisa e da extensão, como eventos, cursos e projetos.

O GEFOPI teve início no Câmpus São Luís de Montes Belos da UEG, e tem desenvolvido seus trabalhos há mais de onze anos, visto ter sido criado em 2006, produzindo além de conhecimentos a integração de acadêmicos e egressos de vários Câmpus da Instituição, bem como professores e comunidade em geral. Os componentes do grupo estão espalhados pelo estado de Goiás, nas cidades de Anápolis, Luziânia, Valparaíso de Goiás, Mineiros, São Luís de Montes Belos, Formosa, Jussara, Novo Brasil, Itapirapuã, Fazenda Nova, Sanclerlândia, Aurilândia, Cachoeira de Goiás, Itapuranga, Palmeiras de Goiás, Inhumas, Buriti de Goiás, Planaltina, Trindade, Goiânia e outros. Pode-se afirmar que este grupo de estudos tem a concepção acadêmica processual-orgânica, conforme discute Reis (1996).

Data que entre o período de 2006 e 2012 ocorreu o desenvolvimento do grupo com atividades de ensino, pesquisa e extensão. No ensino, a partir de encontros semanais, individuais ou em pequenos grupos, ocorreram as orientações àqueles com dificuldade na leitura, interpretação e escrita. Na pesquisa, iniciou-se o desenvolvimento de vários projetos de pesquisa, inclusive com bolsistas financiados pela instituição; e na extensão da mesma forma.

Em 2012, houve um aumento significativo de projetos e publicações lançados nacional e internacionalmente. Em 2015, o GEFOPI se expandiu territorialmente, iniciando os estudos também com um grupo de acadêmicos e professores do Câmpus Jussara da UEG. Em 2017, uma nova jornada de expansão foi iniciada: agora para o Câmpus Luziânia e o Câmpus Formosa da UEG. Em 2018 nova expansão, chegando aos Câmpus Trindade e Inhumas. Almeja-se demarcar uma nova era para o GEFOPI - expansão territorial e acadêmica.

Um grupo de estudos pode transcender os muros do ensino, propiciando a investigação científica, a socialização de saberes e a produção acadêmica e por ser de concepção acadêmica, com características processual e orgânica, 
em um processo contínuo de ações organizadas e sistematizadas no intuito da transformação do real e da formação dos acadêmicos. Nesse limbo, uma das atividades do GEFOPI, iniciadas em 2017 foi o ENFORMA - Encontro de Formação de Professores, realizado em Luziânia - GO.

Destarte, o objetivo desse artigo é apresentar a experiência do ENFORMA, como um projeto de extensão pela concepção acadêmica, processual e orgânica. A discussão sobre a extensão acadêmica, processual e orgânica ainda está em processo de compreensão e pouco presente no cenário de debates e pesquisas. Para tal organizamos o artigo em três sessões, sendo que a primeira discute a concepção acadêmica, processual e orgânica de extensão universitária, a segunda apresenta o projeto de extensão ENFORMA e a terceira socializa as atividades realizadas do ENFORMA.

A EXTENSÃO ACADÊMICA, PROCESSUAL E ORGÂNICA: CONCEPÇÕES, SENTIDOS E CONSTRUÇÕES

Discutir a extensão universitária no Brasil perpassa por compreender suas concepções, seus sentidos e suas construções, principalmente quando se associa a formação de professores. Para o diálogo sobre essa temática nos embasamos em Reis (1996), Síveres (2013) e Jezine (2004). Para favorecer o diálogo e iniciar a caminhada reportamos a questões históricas e legais.

A extensão universitária brasileira tem uma constituição histórica de influências europeias e norte americana quanto à concepção e o sentido de atividades extensionistas. Por muitos anos a concepção foi de prestação de serviços e assistencialismo, em que o papel da Universidade era meramente suprir as demandas sociais e do mercado. Nos últimos anos a concepção começa a dar sinais de mudanças, caminhando para a constituição da concepção acadêmica, com característica processual e orgânica, segundo Reis (1996).

No tocante a legalização da extensão universitária no Brasil é preciso nos reportamos a tempos outrora, em 1988, quando a Nova Constituição, em seu Art. 207 apresentou que as universidades obedecerão ao princípio de indissociabilidade entre ensino, pesquisa e extensão. Também nos reportamos a 1996, com a nova LDB n. 9.394, em seus Art. 43, 44, 52, 53 e 77, que tratou da indissociabilidade pesquisa, ensino e extensão e de bolsas de estudos. Bem como, em 2001 com o Plano Nacional de Educação (PNE) em suas Metas 21, 
22 e 23, que defendia a extensão como princípio formativo obrigatório. Também em 2001 é criado o Plano Nacional de Extensão Universitária (PNEU) que defendeu a curricularização no processo formativo da concepção acadêmica, reforçada pelo Plano Nacional de Extensão Universitária (PNEU) de 2011 que discutiu a obrigatoriedade de curricularização de 10\% dos créditos total do processo formativo em projetos e programas de extensão universitária. Essa curricularização foi defendida também pelo Plano Nacional de Educação (PNE) de 2014 em sua Meta 12.7 ao apresentar que até 2015 os currículos dos cursos universitários, sejam bacharelado ou licenciatura, deveriam destinar $10 \%$ da carga total de créditos dos cursos a formação por via de projetos e programas de extensão.

Com esse pano de fundo é que a concepção e o sentido de atividades de extensão para a prestação de serviços e assistencialismo começam a dar sinais de finitude ou adaptações significativas, cedendo lugar para a concepção acadêmica que prima pela formação dos envolvidos, enquanto acadêmicos, ao passo que transforma o real com as atividades desenvolvidas e não somente atendem as demandas sociais e ao mercado.

A construção de atividades extensionistas pela concepção acadêmica tem o sentido de transformação tanto da sociedade quanto principalmente do acadêmico durante seu processo formativo inicial. Para Jezine (2004) a concepção da extensão deve ser acadêmica e seu sentido deve ser o de promover a consciência crítica e sua construção deve ser com ações que visem a transformação. Dessa forma, a autora enfatiza que

\footnotetext{
a extensão como uma função da universidade, objetivando se firmar a partir da concepção acadêmica, inserida no contexto de contradições inerentes ao próprio processo de produção do conhecimento em uma sociedade capitalista, busca uma nova dimensão de universidade, sociedade e sujeito, consubstanciada na perspectiva ideológica do "compromisso social" como instituição pública, viabilizando a organização política do grupo, em que além da promoção de uma consciência crítica se almeja a intervenção na realidade em um perspectiva transformadora e libertadora, da autonomia do sujeito (JEZINE, 2004, p. 4).
}

Esta autora defende a extensão na concepção acadêmica, criticando a mera formação técnica, o currículo fragmentado e a manipulação, ao enfatizar que

o trabalho da extensão universitária numa perspectiva acadêmica pretende assim, ultrapassar o limite da ciência técnica, do currículo fragmentado e da visão de homem como objeto a ser manipulado, encaminhando-se para uma visão multidimensional, em que as 
dimensões político-social-humana estejam presente na formação do sujeito, concebido como ser histórico (JEZINE, 2004, p. 4).

Nessa perspectiva, Síveres (2013, p. 8) defende que a concepção e sentido de extensão universitária precisa romper com a mera prestação de serviços e dar uma conotação acadêmica as atividades extensionistas, uma vez que

a extensão universitária, portanto, também passa por um processo de reflexão e de revisão de seu papel, e é indiscutível seu caráter estratégico para a formação dos estudantes em uma perspectiva mais integradora, concreta e concatenada com a realidade. De cumpridora do papel social da universidade, passando pela prestação de serviços ou como sua atividade-fim, a extensão assume uma conotação mais acadêmica e fortemente vinculada às necessidades da sociedade.

Sobre a extensão universitária, Reis (1996, p. 41) discute duas concepções, cada uma com seu sentido: a processual-orgânica e a eventista-inorgânica, apresentando que a concepção eventista-inorgânica configura "como característica a prestação de serviços ou na realização de eventos, isolados ou desvinculados do contexto ou do processo ensino-aprendizagem e de produção do conhecimento da universidade.". As ações da concepção conceitual eventista-inorgânica ocorrem eventualmente aproximando as concepções de ação assistencialista ou prestação de serviços, em que seu sentido é meramente atender a demanda do mercado ou camuflar uma realidade social. Assim, a construção de atividades extensionistas podem não envolver acadêmicos ou não denotar construções teórico-práticas e produção do conhecimento.

Reis (1996) apresenta que as atividades de extensão na concepção processual-orgânica se caracterizam por ações permanentes ou contínuas, que se relacionam de forma indissociável com o ensino e a pesquisa, primando pela transformação do real e parceria oxigenante entre sociedade e academia, fomentando a concepção e o sentido acadêmico das atividades extensionistas no processo formativo. Dessa forma, a extensão

tem como característica o desenvolvimento de ações de caráter permanente, imbricados ou inerentes ao processo formativo (ensino) e à produção de conhecimento (pesquisa) da universidade, em parceria político-pedagógica com a sociedade civil ou política, numa dimensão mutuamente oxigenante e mutuamente transformante (REIS, 1996, p. 41). 
O autor defende que a concepção processual-orgânica da extensão se apresentava já na década de 90 , como a possibilidade para uma universidade comprometida com a transformação social e com o processo formativo pelas vias do ensino, pesquisa e extensão, e apresenta algumas consequências ou problematizações que deveriam ser consideradas para tamanha ruptura, visto que a extensão até o momento tinha servido ao capital e agora, despontava rumo ao atendimento acadêmico e social. Eis as consequências:

a) Redefinição Político-Filosófico da Universidade [...]; b) Democratização e Redistribuição do Poder da Universidade [...]; c) Acordar e Consorciar Interesses [...]; d) Coragem de 'sujar as mãos' [...]; e) Redirecionar conteúdos de ensino/pesquisa [...]; f) Modificar o conceito de aula e sala de aula [...]. g) Articular as várias instâncias decisórias da universidade [...]; h) A alocação orçamentário-financeira [...]; i) A alocação e a relocação da carga horária ensino, pesquisa e extensão/administração [...]; j) A construção do ensino, pesquisa, extensão na convivência com o diferente, na diferença e com amor [...] (REIS, 1993, p. 29-33).

Para Reis (1996), a universidade tem como função produzir o saber e viabilizar a formação do acadêmico, visando sua transformação pessoal e social inserido em determinado contexto e essa formação pode vir a ser por ações extensionistas, organicamente pensadas e realizadas de forma processual e contínua. Para Reis (1993, p. 41) a sociedade “É o 'lócus' co-participante na formação do profissional e na geração do conhecimento da sociedade".

Destarte, a extensão universitária precisa ser entendida como um processo e não uma simples intervenção, como formação acadêmica e não como prestação de serviços e assistencialismo, como transformação do real e não medida paliativa e mercadológica. Assim, o que está oficializado em documentos legais passa a ser uma realidade no processo formativo. A formação acadêmica pode se dar pela construção de atividades de extensão com a concepção acadêmica, processual e orgânica, alcançando o sentido de formação crítica. Eis, os motivos pelos quais o GEFOPI efetiva o ENFORMA.

O ENFORMA: UM PROJETO DE EXTENSÃO UNIVERSITÁRIA ACADÊMICA, PROCESSUAL E ORGÂNICA

Na sociedade contemporânea em que as inovações tecnológicas são um fenômeno internalizado na cultura que banaliza o conhecimento em favor das 
informações; e na qual, segundo Moreira (2013), ainda há a crença de que qualquer pessoa pode ensinar, bastando para isso conhecer o conteúdo a ser transmitido, é necessário discutir a formação docente. Essa formação precisa ser entendida enquanto um processo, tanto no momento inicial quanto de forma continuada, pois há elementos que norteiam todo esse processo formativo.

A formação de professores perpassa pela universidade, em seu momento inicial, e também pelas experiências em cursos de formação que podem vir das atividades de extensão universitária. Por isso, é importante que a concepção de extensão deixe de ser assistencialista e de prestação de serviço e assuma a acadêmica, processual e orgânica para que a universidade cumpra seu papel de produção de saber em parceria com o saber da comunidade externa e, assim, possa viabilizar a formação tanto do acadêmico quanto dos demais envolvidos com vistas à transformação pessoal e social.

Primando pela concepção acadêmica de caráter processual e orgânico pela práxis crítico-emancipadora que o GEFOPI desenvolve suas atividades e planejou o ENFORMA - Encontro de Formação de Professores do Câmpus Luziânia. Este Encontro surgiu a partir das conversas da coordenadora do GEFOPI com a diretora do Câmpus Luziânia da UEG que apresentou uma demanda advinda da Secretaria de Educação do Município no que tange à pouca oferta de formação continuada para os professores da rede municipal. Após vários encontros discutindo as possibilidades e as dificuldades de organização de atividades como a formação continuada de professores a um grupo de estudos que tem a visão de extensão universitária acadêmica processual-orgânica, chegou-se ao ENFORMA, que pode propiciar momentos de diálogos sobre teorias, didática e práticas de ensino na Educação Infantil e Ensino Fundamental, visto que a formação destina-se aos professores desta etapa da Educação Básica.

A oferta de atividades de formação continuada deve ser pensada não apenas como uma prestação de serviço da universidade à comunidade, mas também como uma atividade de extensão que prima pela concepção acadêmica em todo processo de formação, seja inicial ou continuada. Assim, o ENFORMA foi pensado para ser mais uma atividade do GEFOPI, que envolveria o ensino, a pesquisa e a extensão, como objetivo de formação inicial e continuada, por meio de didáticas e práticas de ensino variadas que possibilitem a reflexão e aprendizagem para transformações nas ações docentes.

Enquanto ensino, suas atividades abordariam a gestão de todo o evento, como o espaço, a divulgação, a acolhida dos participantes, o cronograma e a 
execução de forma em geral, para além de questões didáticas. Enquanto pesquisa, as edições do ENFORMA são organizadas para que as atividades envolvam palestras, mesas redondas, oficinas e outras metodologias que primem pela discussão de teorias vinculadas às pesquisas desenvolvidas por membros do GEFOPI já concluídas ou em andamento. Inclusive, o próprio ENFORMA é objeto de uma pesquisa coordenada pela docente Maria Eneida da Silva com a colaboração das professoras Andréa Kochhann e Maria Cecília, tendo como alunas de iniciação científica acadêmicas de Pedagogia do Câmpus Luziânia e integrantes do GEFOPI. Enquanto extensão, a própria ação de abrir o espaço da universidade para atender a uma necessidade da comunidade agregada ao processo orgânico e processual do projeto com o envolvimento dos acadêmicos do curso, configura a extensão universitária.

Diante disso, cumpre ressaltar então que os pesquisadores, debatedores e organizadores de todo o evento são partícipes do GEFOPI que conta com a participação de acadêmicos (as) no credenciamento; na recepção ao público; na condução do cerimonial; na certificação; acadêmicos (as) e docentes nas mesas redondas, palestras e oficinas. As coordenadoras do GEFOPI, professoras Andréa e Maria Eneida, reúnem-se com os partícipes do grupo para o planejamento de cada atividade do evento, inclusive questões como vestimenta; imposição de voz; fluidez leitora; ornamentação; e toda a logística do Encontro desde as inscrições até a certificação entregue em cada evento.

O ENFORMA contou com três edições no ano de 2017, envolvendo professores, palestrantes e principalmente acadêmicos do curso de Pedagogia da UEG que estiveram motivados à preparação do evento em diferentes atuações. Tal integração fortaleceu a formação inicial destes acadêmicos cuja participação garantiu a organização e a qualidade dos eventos. Como mostra a imagem 1, no momento do credenciamento e na imagem 2 no cerimonial do I ENFORMA. 
IMAGEM 1 - Credenciamento

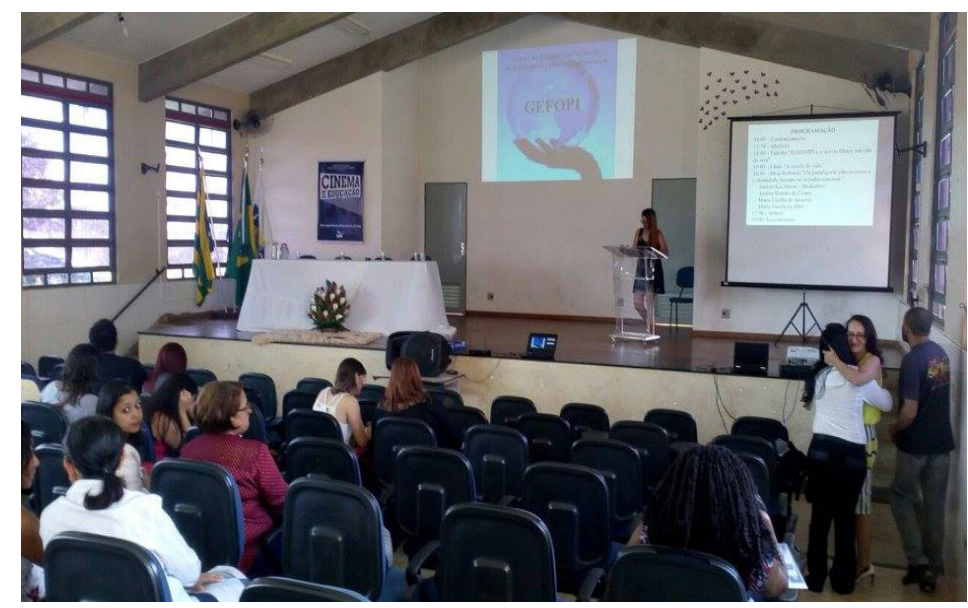

IMAGem 2-Cerimonial do evento

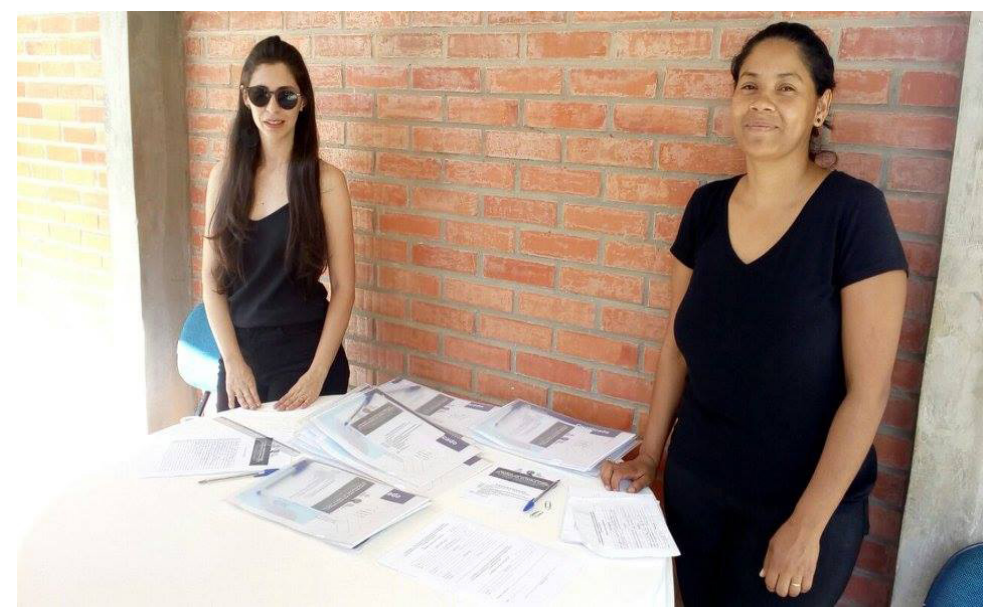

FONTE: ACERVO DO GEFOPI (2017).

O I ENFORMA teve como temática central a discussão sobre "Os paradigmas educacionais e a identidade docente no trabalho concreto". As inscrições para o evento foram realizadas antecipadamente e de forma presencial na Secretaria Acadêmica do Câmpus Luziânia da UEG. A proposta de uma tarde de formação se desenvolveu no próprio Campus, das $13 \mathrm{~h}$ às $18 \mathrm{~h}$, no dia 26 de maio de 2017, tendo início com uma palestra sobre o uso de filmes na sala de aula. Logo após, houve a exibição do filme "A escola da Vida" que inspirou a discussão na mesa redonda.

A palestra foi proferida pela professora mestra Andréa Kochhann que trouxe a importância da intencionalidade ao se trabalhar em sala de aula com filmes, levando os professores presentes a concluírem que não basta levar o 
entretenimento, passar o tempo com o filme, mas torná-lo objetivo de aprendizagem. Assim seguiu- se a programação com a exibição de um filme de cunho educacional.

O filme "A escola da vida" foi exibido e apreciado por todos os presentes degustando pipoca. Momento de aprender sobre o enredo que trazia a história de dois professores diferentes em metodologia, mas que demonstraram a necessidade de aprender um do outro para melhorar sua prática pedagógica. A partir do enredo apresentado, iniciou-se a mesa redonda composta pela professora mestra Maria Eneida da Silva, pelo professor Andrey de Castro e pela professora especialista Maria Cecília Silva de Amorim, cuja mediação foi da professora Andréa.

A mesa redonda, representada na Imagem 3, discutiu os pressupostos teóricos presentes no filme. Cada integrante da mesa trouxe sua visão teórica, citando vários autores como Freire, Saviani, Demo e outros que possibilitaram agregar conhecimento teórico a todos os partícipes do evento. Esse momento do evento foi transmitido via Skype, possibilitando a outros integrantes do GEFOPI acompanharem a exposição teórica com qualidade, como mostra a Imagem 4.

IMAGEM 3-Mesa de debate

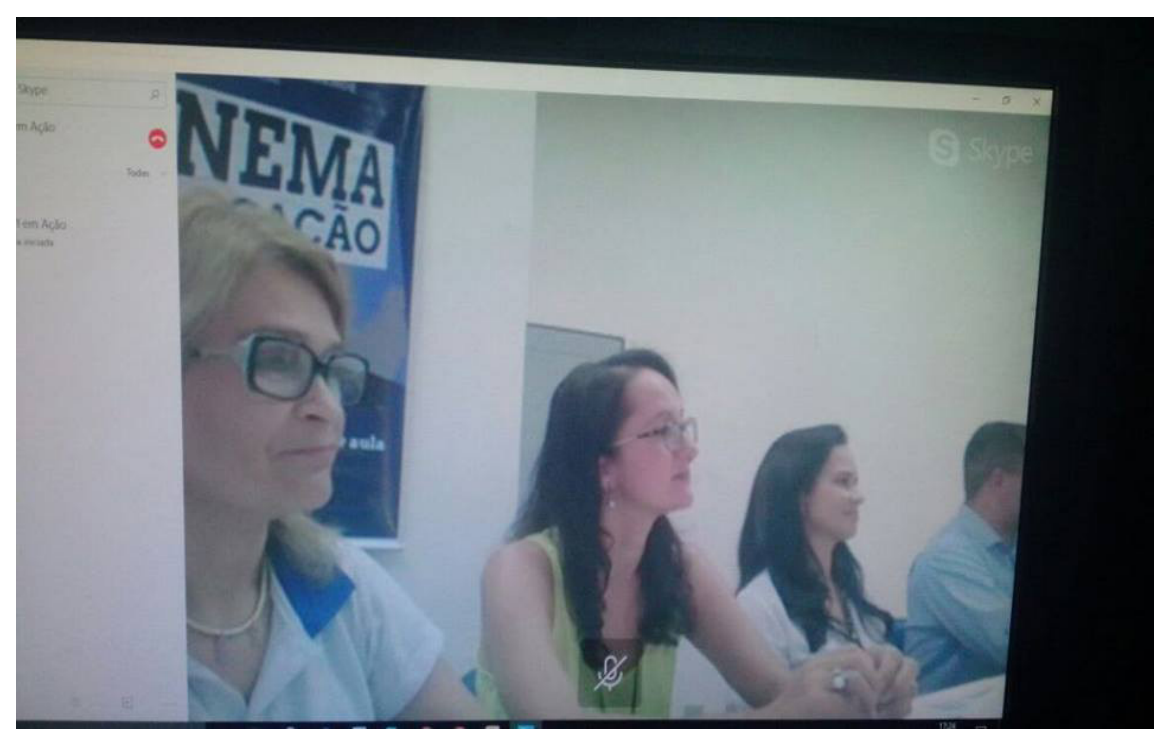


IMACEM 4-Transmissão via Skype

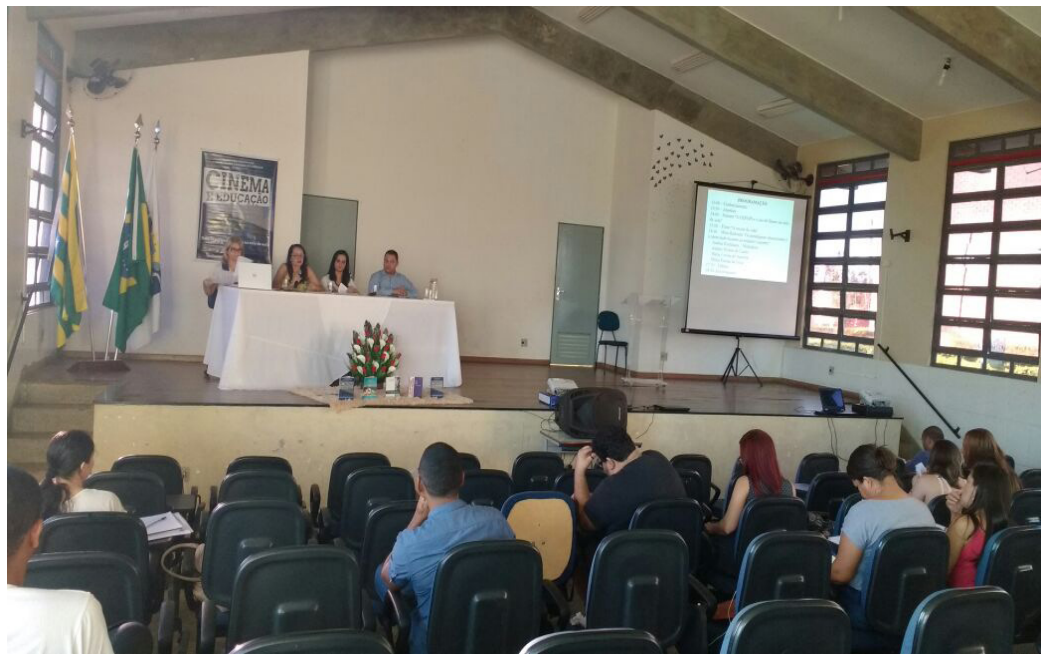

FONTE: ACERVO DO GEFOPI (2017)

A mediação consolidou as falas dos componentes da mesa trazendo pesquisa, práxis, interdisciplinaridade, pedagogia tradicional e renovada como centro do debate que foi bastante envolvente e motivador a questionamentos, como apresenta a Imagem 5. O encerramento foi marcado pela entrega de livros aos participantes da plateia, conforme mostra a Imagem 6, escolhidos exatamente por terem levantado questões significativas ao debate. Dentre estes, estudantes de administração, estudantes de pedagogia e professores da rede municipal de ensino.

IMACEм 5-Participação do público

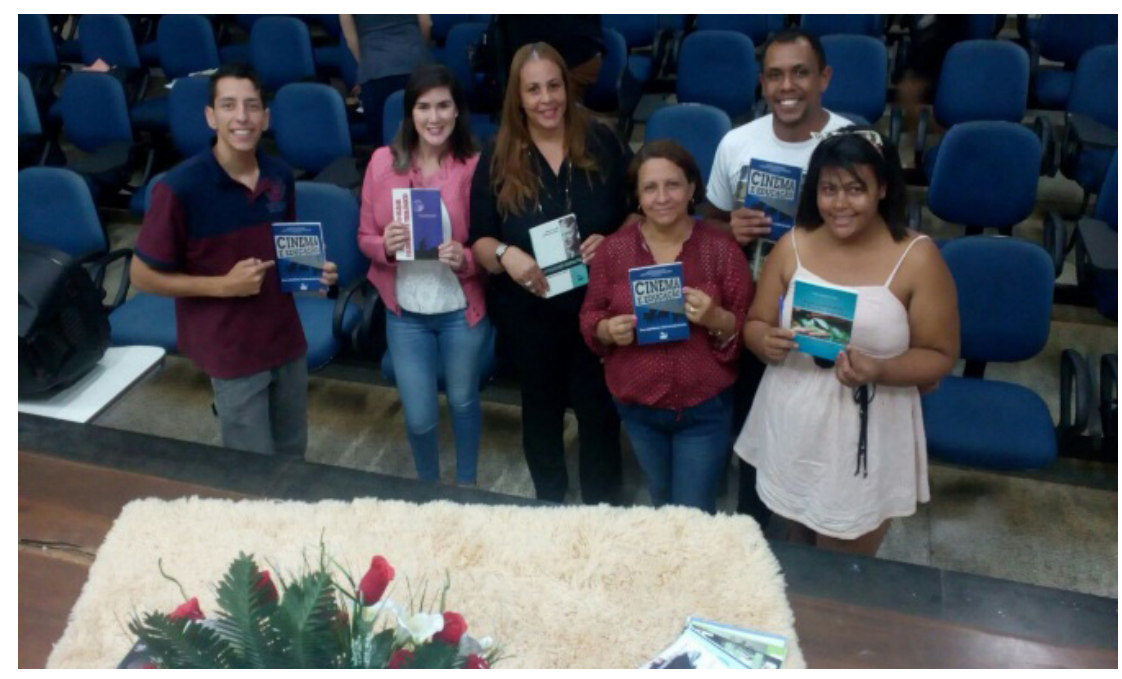


IMAGEM 6-Ganhadores dos livros no sorteio

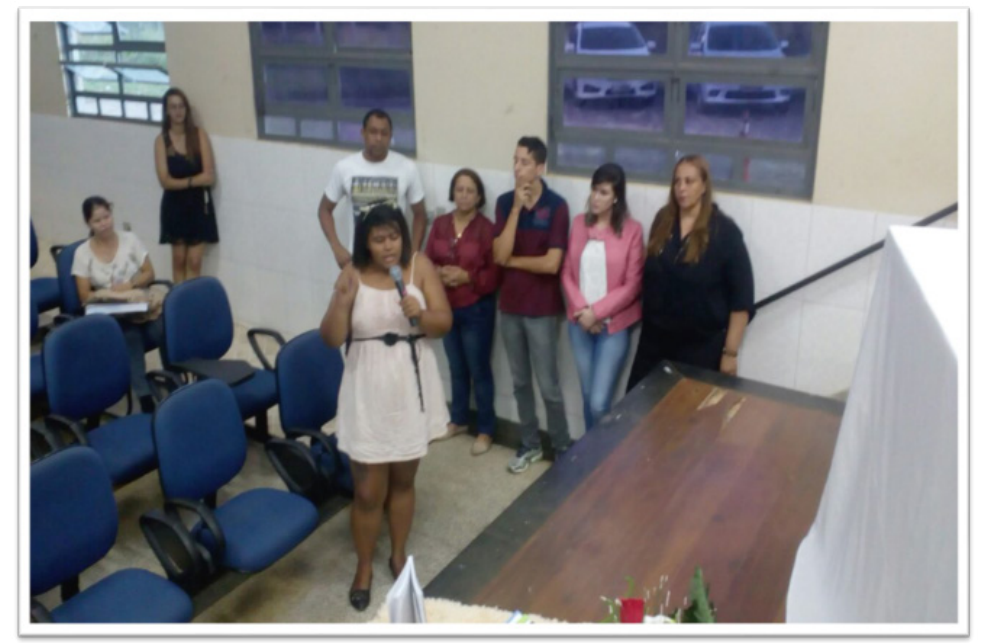

FONTE: ACERVO DO GEFOPI (2017)

A segunda edição do ENFORMA trouxe a discussão sobre " Letramento, didática fundamental e tendência histórico crítica: diálogos fecundos” e contou com a participação dos membros do GEFOPI para organizar todo o evento, porém diversificando-se as funções, de maneira que se pudesse experimentar outras atividades. Assim, quem credenciou, agora iria peparar o cerimonial, quem palestrou, realizaria mediação, gerando oportunidade a todos de aprenderem e experimentarem funções diferentes.

O II ENFORMA aconteceu dia 29 de setembro, nos períodos matutino e vespertino e as inscrições foram realizadas via e-mail, visando facilitar a participação de todos. Dada a proximidade ao "Dia das crianças" foi solicitado no ato da inscrição, um brinquedo que seria doado posteriormente. Após a abertura oficial realizada pela diretora da UEG, foi proferida a palestra sobre o GEFOPI e sua origem por acadêmicas do curso de Pedagogia , como mostram as Imagens 7 e Imagem 8. 
IMAGEM 7-Palestra sobre o GEFOPI por acadêmicas de Pedagogia

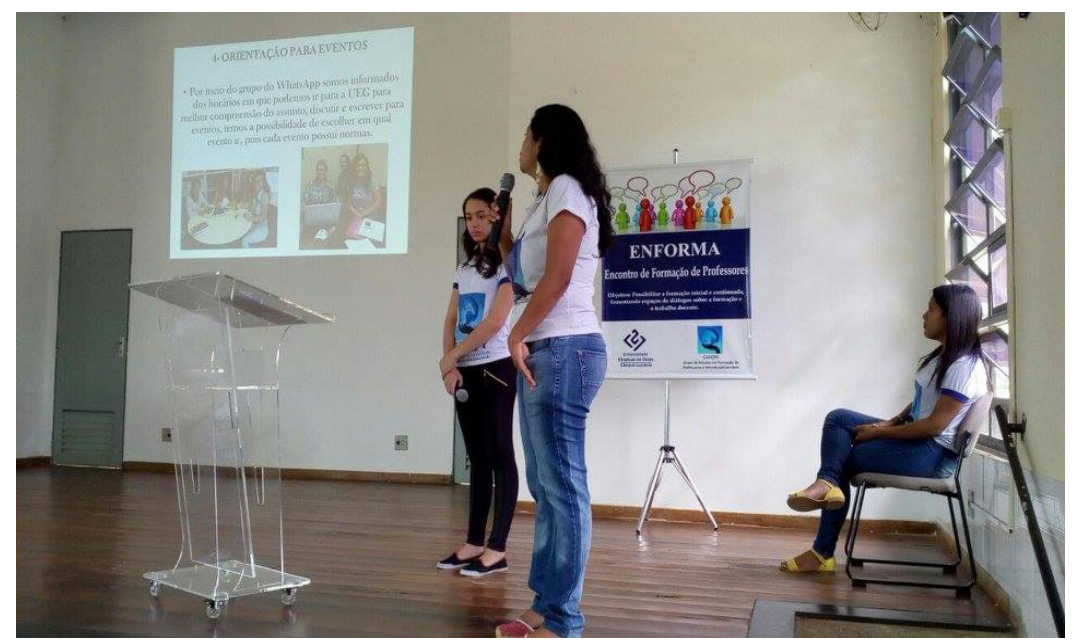

IMACEM 8-Palestra sobre o ENFORMA Pedagogia

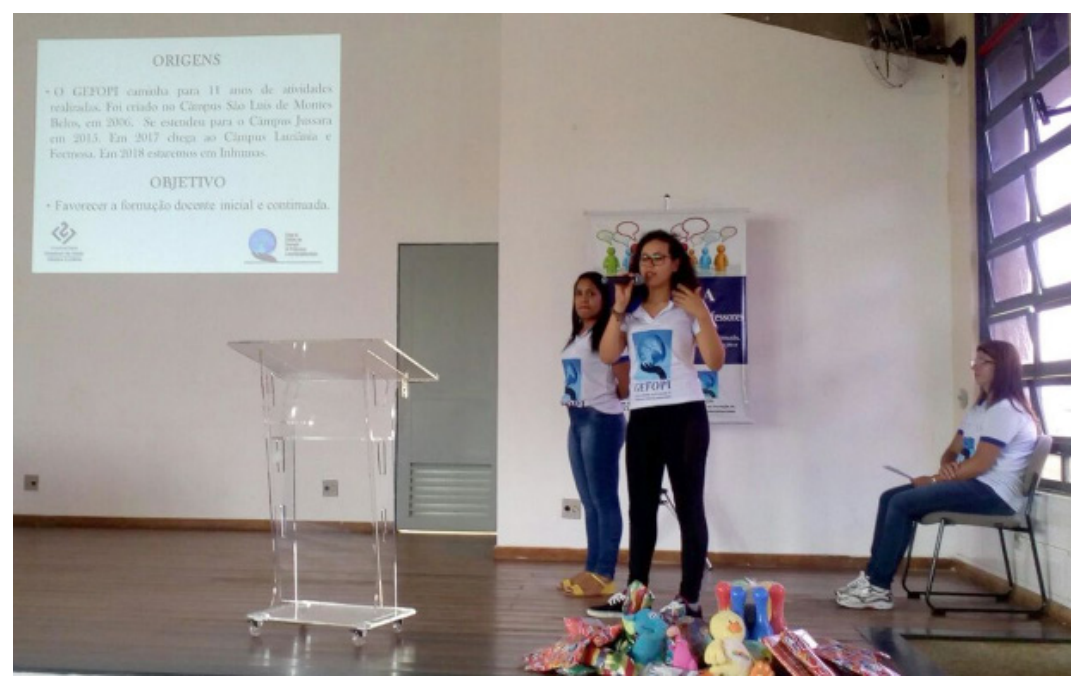

FONTE: ACERVO DO GEFOPI (2017)

A mesa redonda foi composta pela professora mestra Maria Eneida da Silva, então diretora do Câmpus Luziânia da UEG; pelo professor Samuel Pedro Gonzaga, integrante do GEFOPI e residente no município de Itapuranga; e pela professora mestra Andréa Kochhann, sendo a mediação realizada pela professora especialista Maria Cecília Silva de Amorim. O diálogo promovido foi bastante profícuo, uma vez que o tema fora tratado por cada membro da mesa e interligado de maneira interdisciplinar.

O letramento, tratado pela professora Maria Eneida foi foco de bastante reflexão com base em termos como os multiletramentos, e diversos 
processos de letramento: político, digital, literário e outros. O uso de imagens criativas e a utilização de desafios como o enigma: "O que Adão e Eva têm de diferente dos demais homens e mulheres?" que envolveu os participantes, motivados em descobrir a resposta, a partir da qual se iniciou a exposição teórica. Os principais teóricos destacados foram Freire, Antunes, Street, Cosson, Marcuschi dentre outros.

O professor Samuel trouxe a discussão sobre a didática fundamental, abordando principalmente textos de Candau, trazendo a multimensionalidade da didática nas relações e na formação profissional, uma vez que é de suma importância perceber o outro e a singeleza do processo que envolve a didática em todos os momentos. O professor apresentou também a diferença de tratamento entre pessoas que utilizam os pressupostos da didática fundamental a partir do momento em que cumprimentam outros na instituição, mostrando que não há status quo que substitua a ética e o tratamento humano entre as pessoas. A didática é inerente ao ser humano.

A professora Andréa abordou a pedagogia histórico-crítica em Saviani, a partir dos estudos e da teoria marxista. Destacou o letramento e a didática como temas relacionáveis, pois são sociais assim como a pedagogia histórico-crítica. Esta vertente teórica prima pela questão da transformação social e as condições para tal transformação. Muito agregou à discussão o aprofundamento sobre práxis em Sanches Vásquez, trazendo a visão de indissociabilidade teoria e prática. Nas Imagens 9 e 10, a apresentação da mesa redonda do II ENFORMA.

IMACEM 9-Fala do prof. Samuel no II ENFORMA

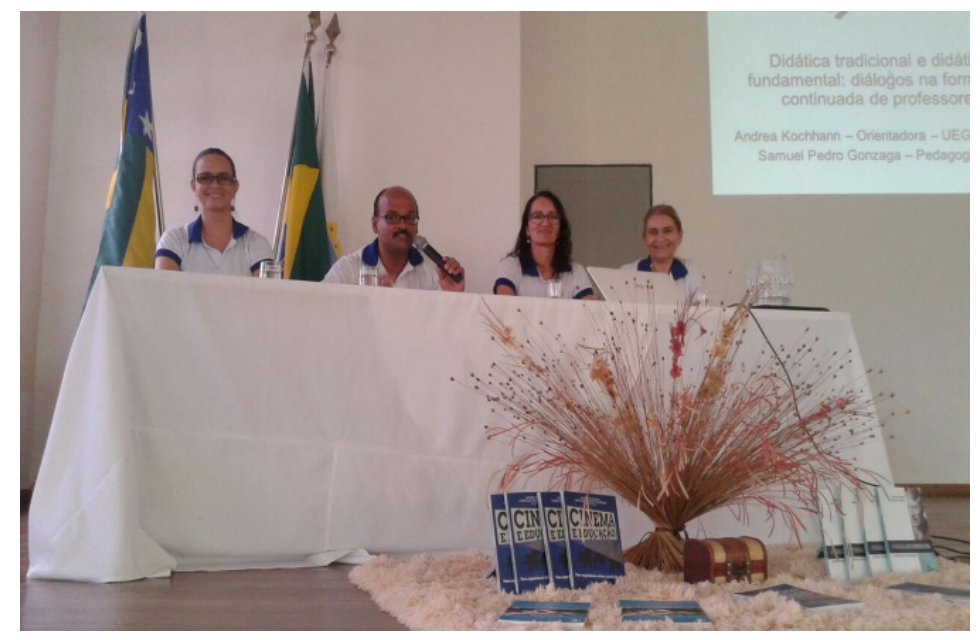


Imacem 10-Mesa de debate II ENFORMA

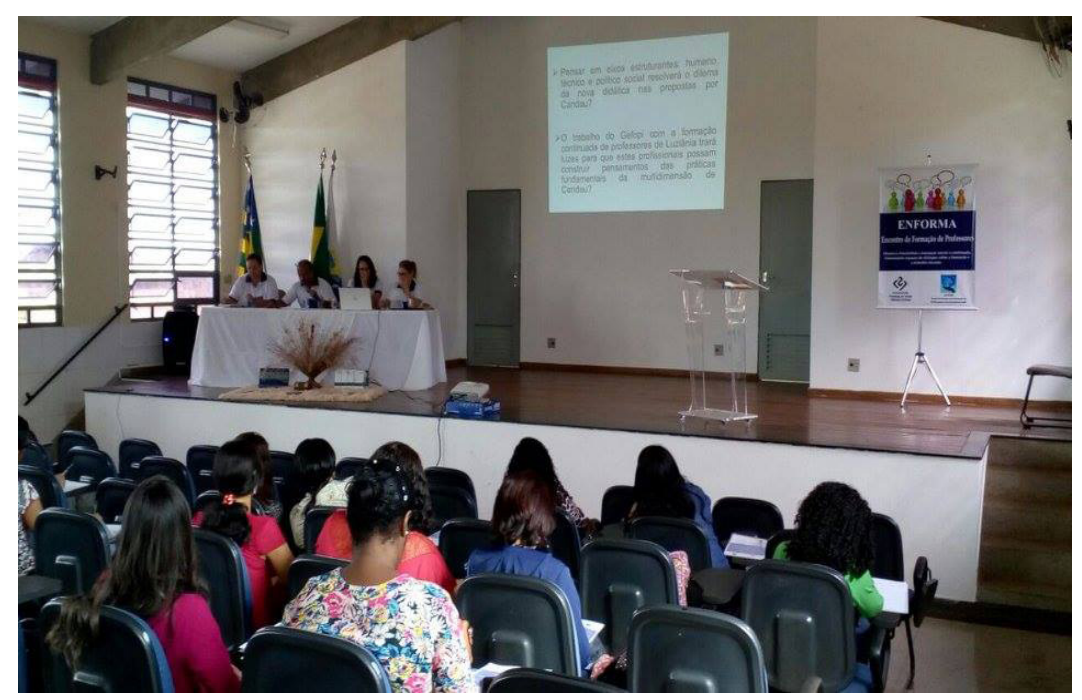

FONTE: ACERVO DO GEFOPI (2017)

A interlocução realizada pela mediação da mesa buscou sintetizar as discussões trazendo à tona outros questionamentos acerca do "chão da sala de aula" e o reconhecimento do trabalho pedagógico a partir do conhecimento proporcionado pela discussão sobre letramento, didática e pedagogia histórico-crítica. Assim, motivou-se a expressão dos participantes mostrada na Imagem 11. Houve ainda sorteio de livros entre os participantes, conforme Imagem 12.

\section{IMACEм 11 - Participação do público}

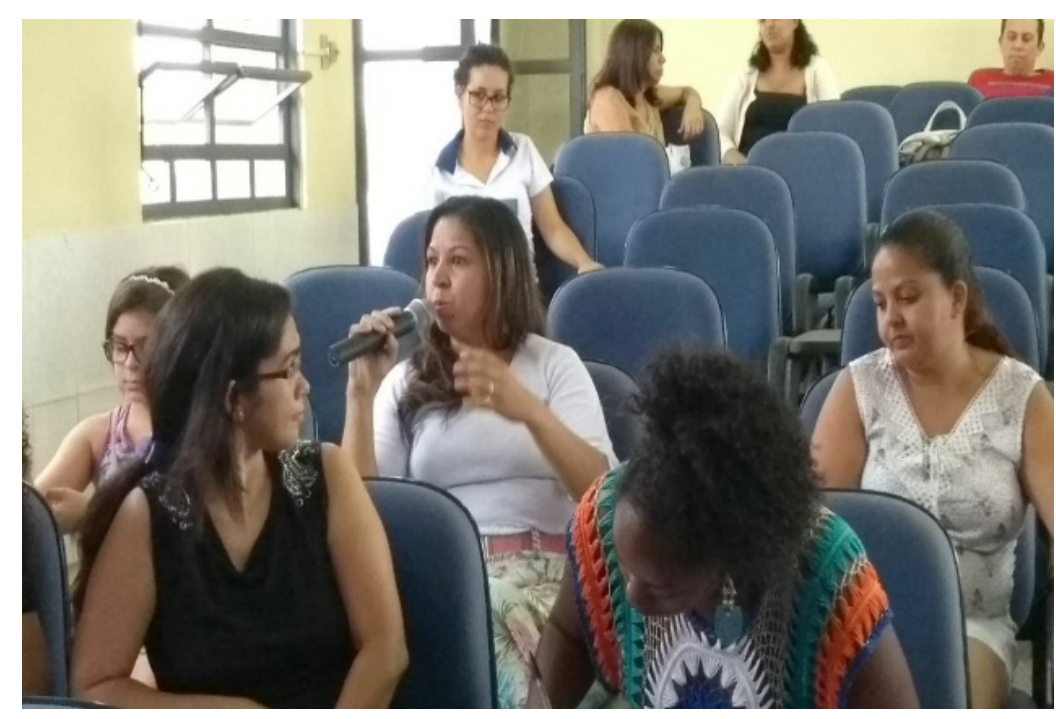


IMACEM 12-Ganhadores dos livros no sorteio

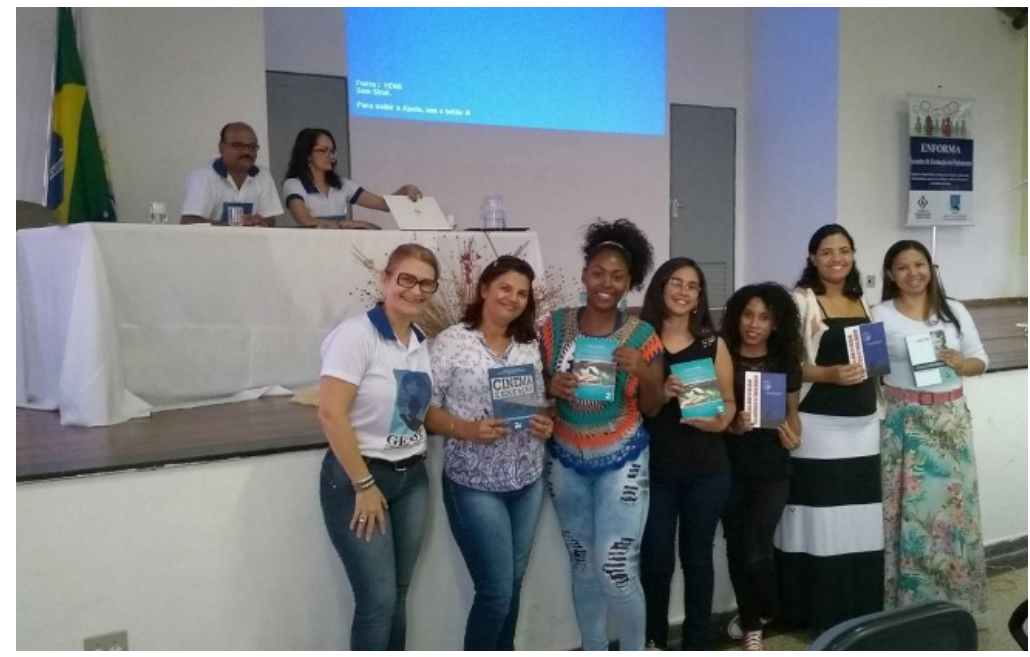

FONTE: ACERVO DO GEFOPI (2017)

O II ENFORMA teve reflexos também na sala de aula de $2^{\circ}$ ano da Escola Municipal Dilma Roriz Medeiros, com a distribuição dos brinquedos arrecadados. Os 16 alunos puderam receber os brinquedos numa ação social, doravante agregada ao ENFORMA e nessa edição intitulada "Criança feliz", como mostra a Imagem 13. A entrega dos brinquedos foi realizada por membros do grupo de estudos GEFOPI que sortearam os itens entre meninos e meninas, conforme a Imagem 14. As crianças demonstraram sua gratidão escrevendo cartinhas de agradecimento aos membros do grupo, cartas estas que foram parte de uma atividade pedagógica da professora a turma no trabalho com os gêneros do discurso.

IMACEM 13-As crianças e os brinquedos

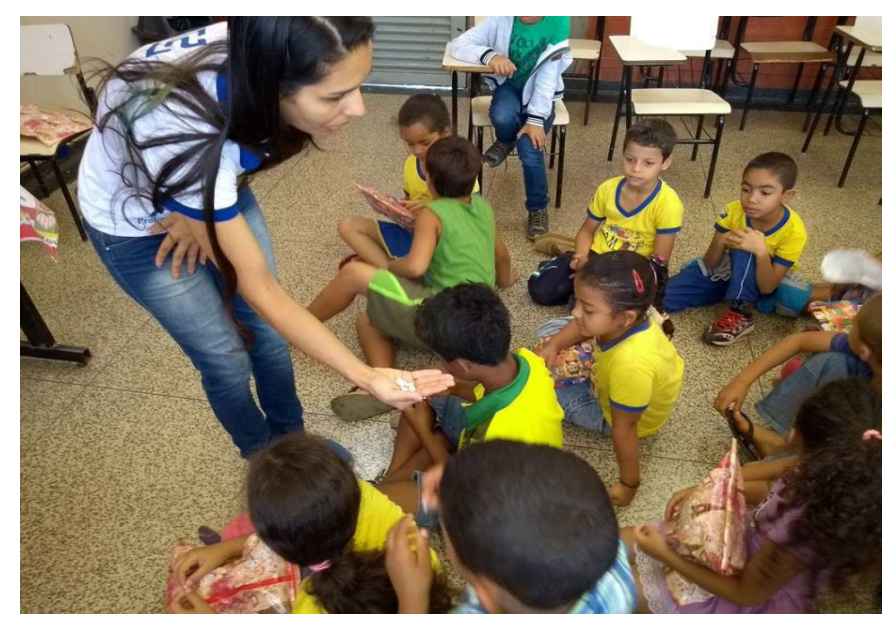


IMACEM $14-0$ sorteio dos brinquedos

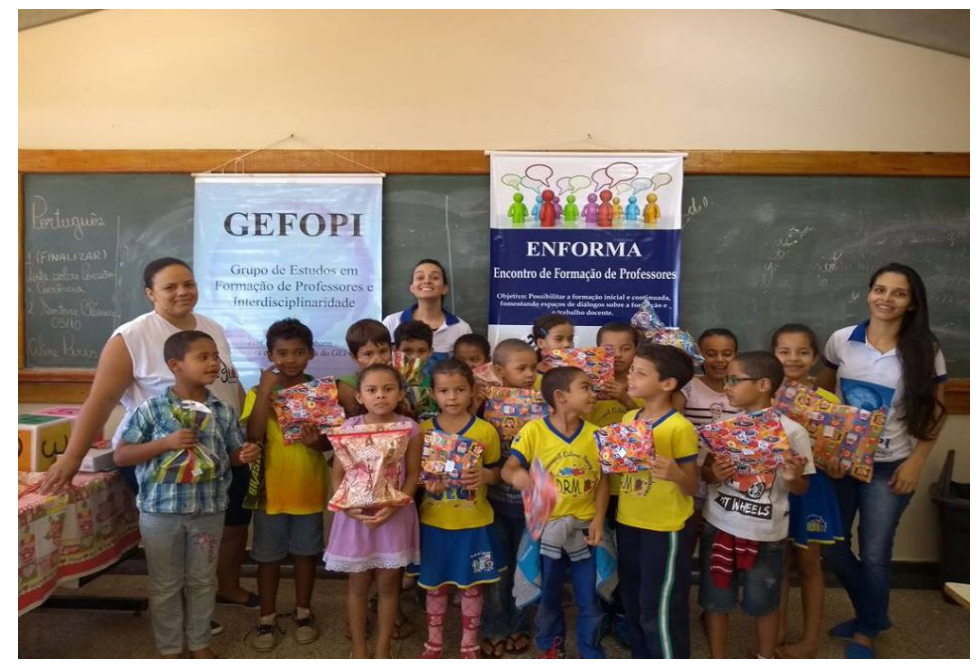

FONTE: ACERVO DO GEFOPI (2017).

No dia 24 de novembro foi realizado o III ENFORMA no período matutino e vespertino. Mais uma vez contou com a organização direta dos membros do GEFOPI e também acadêmicos do curso de Pedagogia da UEG, como mostra a Imagem 15. Nesta edição, foram escolhidas coordenadoras para o evento, estas teriam a função de mobilizar, divulgar e organizar toda a estrutura montada dessa vez numa sala de aula, pois seria mais adequado à realização de oficina, conforme Imagem 16. O tema escolhido foi "Sustentabilidade na sala de aula: teoria e prática", o qual foi ministrado pela professora Dra. Ananda Helena Nunes Cunha docente do Câmpus Anápolis da UEG. Para este evento, foi solicitado a cada participante um quilo de alimento não perecível para a ação social "Natal Solidário". 
IMACEM $15-$ A recepção do evento

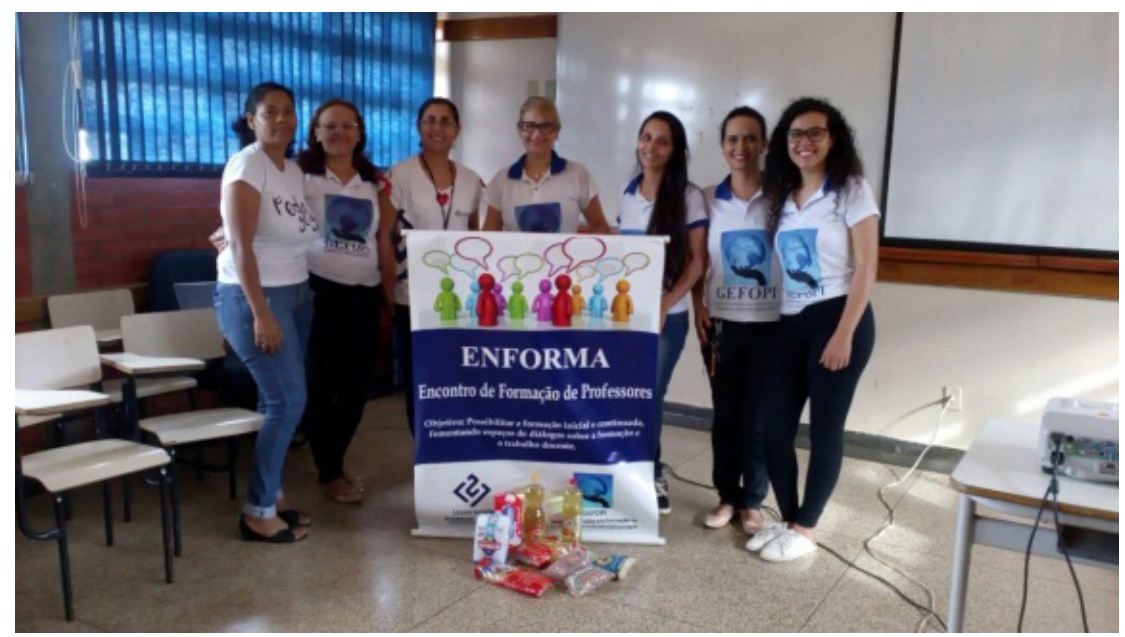

IMACEM 16-Equipe e alimentos arrecadados

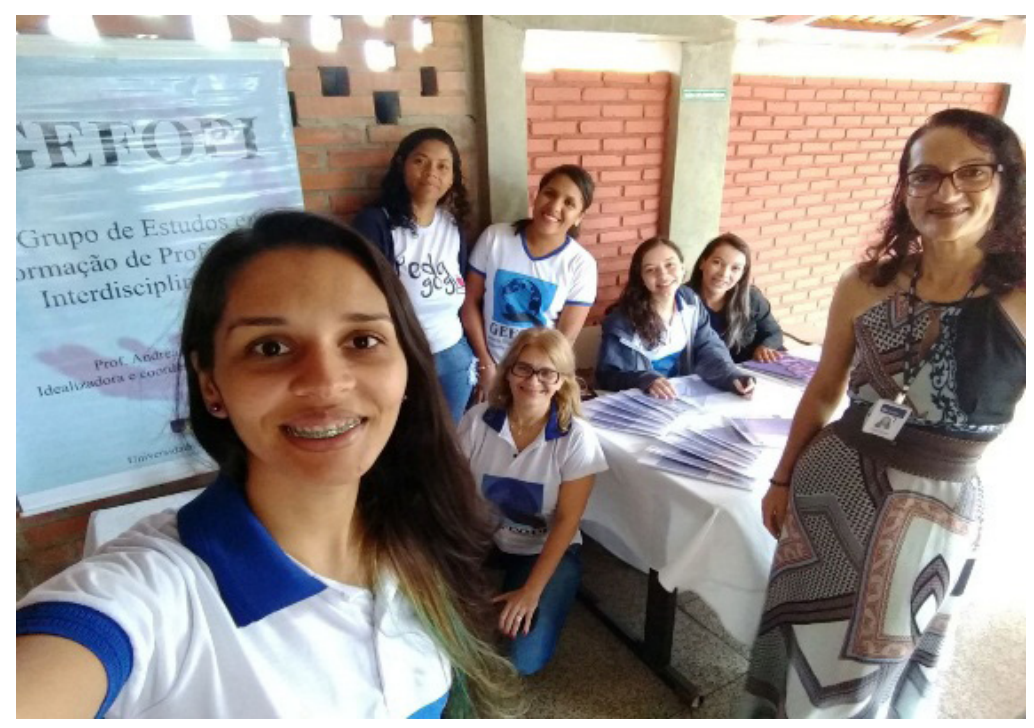

FONTE: ACERVO DO GEFOPI (2017)

A abertura do evento foi realizada pela professora Maria Eneida, diretora do campus. Em seguida, houve a palestra sobre "GEFOPI e ENFORMA" ministrada por acadêmicos da UEG e uma egressa da universidade com o objetivo de socializar a origem e finalidade do GEFOPI e também a importância e os reflexos do ENFORMA como encontro de formação processual e orgânico no tripé da universidade: ensino, pesquisa e extensão.

A oficina de sustentabilidade teve início com a reflexão sobre as atitudes sustentáveis no dia a dia por meio de um questionário. Foi exibido um vídeo que chocou a todos, pois mostrava a análise cadavérica de pássaros que se 
alimentavam no mar e acabavam morrendo com a barriga cheia de plásticos. Utilizando imagens que esboçavam atitudes sustentáveis, a Dra. Ananda palestrou acerca da importância de ser sustentável para que o mundo também seja; adotar um copo é um grande passo, de acordo com a Imagem 17. Após a explanação teórica, os participantes foram levados a um lugar externo. Usando garrafas pet, areia e mudas de capim foi montado um experimento chamado "Simulador de erosão" com o qual ficou demonstrada a importância de manter a cobertura do solo para não ocorrerem erosões, mostrado na Imagem 18. Essa é uma atividade possível de ser realizada na escola para os alunos que estudam sobre o solo desde o ensino fundamental.

IMAGEM 17-Palestra da profa. Ananda

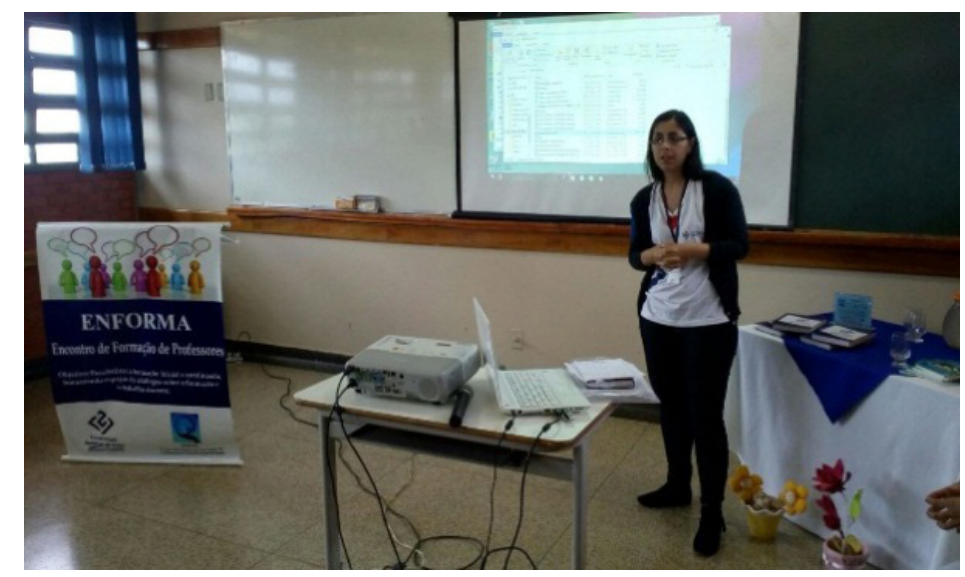

IMAGEm 18-Montando o "Simulador de erosão"

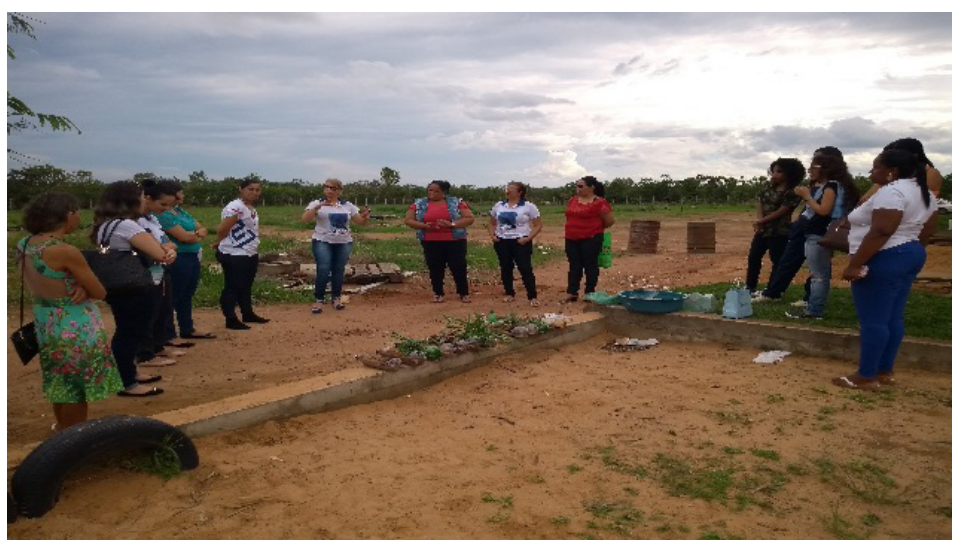

Fonte: ACERVo do GEFOPI (2017)

$\mathrm{Na}$ finalização das atividades teve sorteio de agendas e livros para os participantes, de acordo com a Imagem 19. A ação solidária do ENFORMA 
suscitou a atitude solidária de uma professora de uma escola particular da cidade, que mobilizou a comunidade escolar da qual fazia parte à arrecadação de outros itens além dos que haviam sido conseguidos entre os inscritos no evento. Foram organizadas 6 fartas cestas básicas, Imagem 20, que foram doadas a funcionários terceirizados da UEG que até aquele momento não haviam recebido seu salário. As famílias certamente ficaram bastante gratas pela união de todos em prol desta ação solidária.

IMACEM 19-Entrega de livro sorteado no final do evento

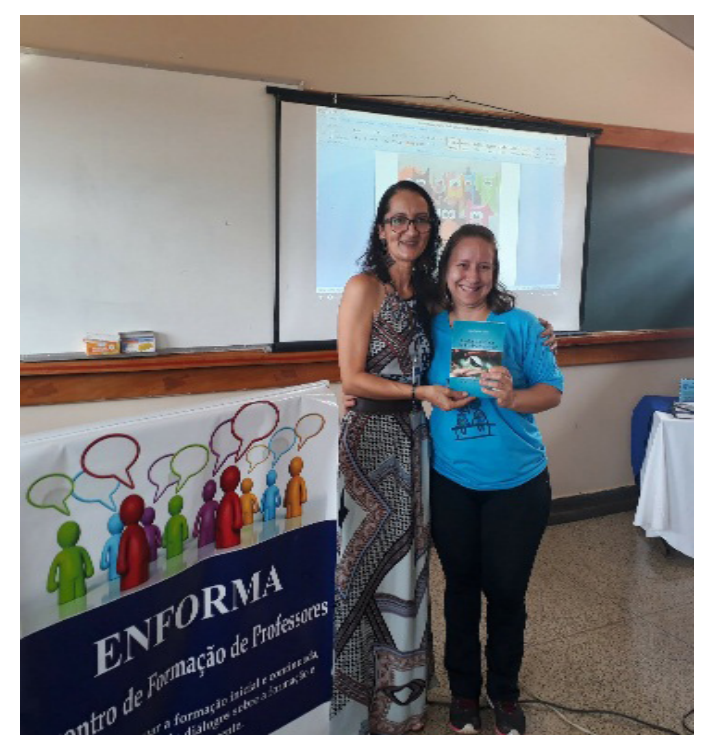

IMACEM 20-Montagem das cestas de alimentos

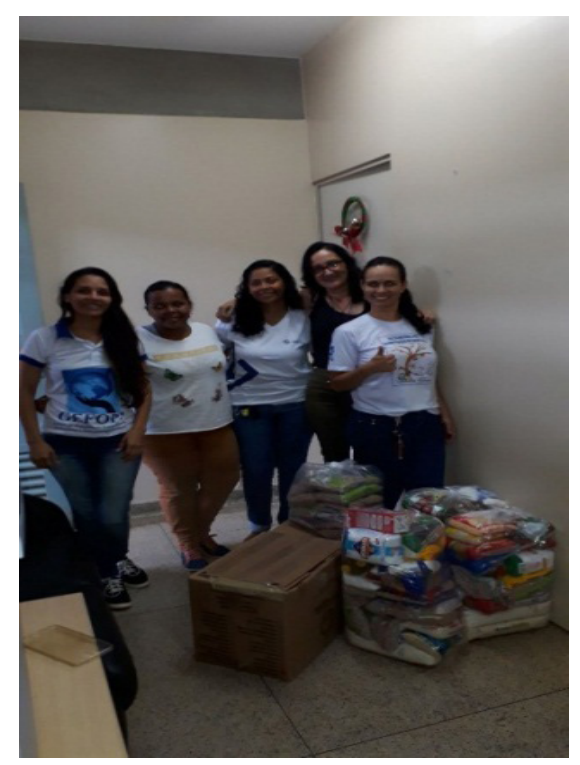

FONTE: ACERVO DO GEFOPI (2017) 
O envolvimento dos acadêmicos nas atividades das três edições do ENFORMA mostrou a congruência entre ensino, pesquisa e extensão universitária alcançada pelo projeto. Os professores participantes demonstraram reconhecer a importância dos temas para sua prática pedagógica, bem como a validade da iniciativa que a cada dia conquista mais adeptos. Os acadêmicos, acadêmicas, egressos e docentes membros do GEFOPI e atuantes no ENFORMA pontuaram diversas contribuições do projeto para sua formação inicial e continuada. Sobre a formação proporcionada pelo Encontro de Formação de Professores, falaremos no próximo tópico.

O ENFORMA: RESULTADOS INICIAIS DE UM PROJETO DE FORMAÇÃO INICIAL E CONTINUADA

Para que se efetive o que Reis (1993) pontua como função da universidade que é a de produzir o saber e possibilitar a formação do acadêmico e da comunidade, visando transformações pessoais e sociais é necessário o desenvolvimento de ações de extensão organicamente pensadas e realizadas de forma processual e contínua imbricadas ao processo formativo - característica do ensino - e também à produção do conhecimento - característica da pesquisa na universidade. Diante disso, o Grupo de Estudos GEFOPI pensou o projeto de extensão ENFORMA para ser realizado como uma formação continuada oferecida aos professores do Ensino Fundamental I do município de Luziânia, da rede pública ou privada de ensino. Para a realização desse projeto, a Secretaria de Educação de Luziânia foi consultada quanto à demanda por formação continuada e a parceria pôde se estabelecer.

A cada edição do ENFORMA é escolhido pela coordenação do projeto uma dupla ou trio diferente de membros do GEFOPI e que, na condição de organizadores, escolhem a equipe de colegas (também membros do GEFOPI). A divulgação do evento é feita por meio de cartazes elaborados pela equipe designada divulgados nas redes sociais e nos e-mails da Secretaria Municipal de Educação de Luziânia, bem como entregues em forma de convite aos diretores e diretoras das escolas da cidade, e às autoridades civis e públicas vinculadas direta ou indiretamente à educação. Os cartazes, mostrados na figura, são desenvolvidos pelos responsáveis por cada edição do evento e supervisionados pelas coordenadoras do projeto, professoras Andréa Kochhann e Maria Eneida. 
Ficura 21-Cartazes das três edições do ENFORMA de 2017
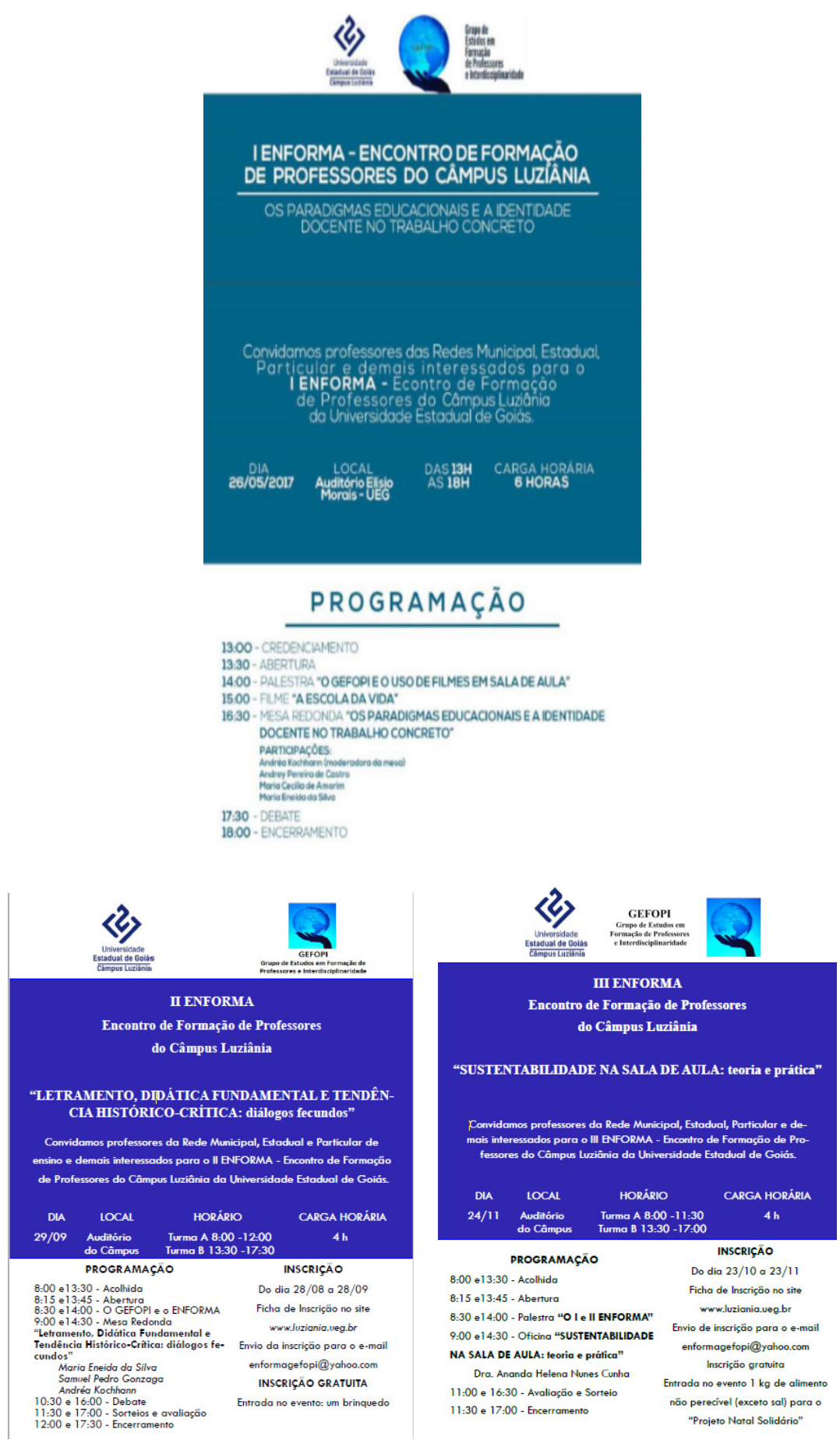

FONTE: ACERVO DO GEFOPI (2017)

Após o I ENFORMA, foi enviada a todos os participantes, por e-mail, uma ficha de avaliação do evento. Nem todos responderam. Dos 34 participantes, 
8 responderam, sendo 4 da comunidade e 4 do GEFOPI, totalizando $24 \%$ de devolutiva. A partir deste resultado e da reunião de avaliação do primeiro evento, optou-se por entregar a ficha avaliativa aos participantes no momento do credenciamento juntamente com a programação e o certificado de participação. Nesta ficha, solicitam-se informações quanto à contribuição do ENFORMA à formação de cada participante, bem como o levantamento dos pontos negativos e positivos de cada encontro.

Por conta das respostas dadas pelos participantes sobre a primeira edição, algumas ações foram tomadas, tais quais: ampliação do tempo e meios de divulgação; criação de um e-mail para as inscrições, visto que a primeira foi somente presencial; realização de dois momentos de formação em cada encontro, uma vez que os professores de um turno cumprem a coordenação em turno contrário ${ }^{4}$; atendimento aos horários de término; preenchimento de ficha de avaliação ao final do evento. Juntamente com tais ações, ficou definido que o ENFORMA também atenderia causas sociais, solicitando como entrada no evento (uma vez que este é $100 \%$ gratuito) alimentos, roupas, brinquedos etc., a depender da campanha empreendida para cada edição do encontro.

Assim sendo, apresentaremos as devolutivas dos participantes como forma de avaliação e pesquisa quanto à contribuição à formação inicial ou continuada pretendida pelo ENFORMA. As respostas dos participantes, tanto público externo quanto membros do GEFOPI, nas três edições, foram muito positivas quanto ao cumprimento do cronograma proposto e ao tratamento dado aos participantes, bem como a importância do espaço para a discussão. Um dos participantes frisou que "Excelente condução dos trabalhos; cronograma bem definido; pontualidade; excelência dos participantes que compuseram a mesa; preocupação com o bem-estar dos praticantes do encontro e com as instalações.".

Uma participante afirmou que foi importante a "Discussão sobre a formação e atuação do professor e o diálogo com a comunidade da rede municipal de ensino". Para outra cursista "A recepção que é a porta de entrada para o evento e o começo do evento foi ótimo, a maneira como foi conduzida a primeira parte foi muito boa, a fala não deixou dúvidas sobre o tema e o porque de estarmos ali". Para outro componente os pontos positivos foram "Envolvimento e seriedade

4 Em Luziânia, os professores cumprem jornada de docência em sala de aula e também tem um período dedicado ao planejamento, chamado de turno de coordenação, que acontece em turnos alternados às atividades de sala de aula. 
do grupo, Conhecimento adquirido, Organização do espaço e Obediência ao tempo e ao cronograma.". Para outra participante os pontos positivos foram "Pontualidade, temas bem abordados e claros, boa recepção e acolhimento, excelente organização.”.

Duas participantes enfatizaram positivamente sobre os temas que são atuais e relevantes, com excelentes palestrantes e local adequado às atividades propostas; boa didática da palestrante, vídeos importantes, recursos excelentes, organização do tempo e envolvimento do grupo. Alguns participantes e membros do GEFOPI pontuaram a pouca divulgação, a pouca participação de professores da rede de ensino e também de acadêmicos de Pedagogia. Uma acadêmica elencou como ponto negativo a pouca divulgação nas salas de aula do curso de Pedagogia e até mesmo de Administração, pois alguns alunos deste curso poderiam se interessar por alguma temática proposta para o evento. Outra participante enfatizou que "O evento foi de suma importância, porém a quantidade pequena de participantes evidencia a falta de compromisso da classe docente quanto ao buscar seu crescimento intelectual.".

No que tange à formação inicial, uma componente do GEFOPI pontuou que "Agregou conhecimentos acerca da importância da pesquisa e atuação dinâmica do professor em sala de aula". Outra componente frisou sua formação: "Desenvolvi o cerimonial do evento. Essa atividade contribuiu para meu processo de desenvolvimento em falar em público o que é de estrema importância para um professor.".

Quanto à formação continuada, um membro do GEFOPI pontuou que "Participei como palestrante da mesa redonda. Quanto à participação na mesa redonda, inicialmente pensei que não conseguiria, pois foi minha primeira vez. Aprendi, antes de tudo, que somos capazes de palestrar sobre assuntos diversos quando nos dedicamos e estudamos para tanto. Minha formação inicial não me permitiu embasamentos teóricos suficientes para falar sobre formação docente. Por isso, a participação no GEFOPI tem sido tão importante para minha formação continuada, visto que tenho aprendido que ser professora é muito mais do que ensinar teoria aos meus alunos em formação docente inicial; é preciso compartilhar com esses alunos e futuros professores a importância de viver aquilo que ensinamos. Fiquei deslumbrada com as teorias de Paulo Freire, Saviani, Gramsci; mas não vivia isso. Hoje, após o GEFOPI, sei que se não viver o que acredito, jamais conseguirei fazer a diferença na vida de alguém, nem mesmo na minha. A participação do ENFORMA foi para mim muito mais do que receber 
um certificado para o Lattes, ou do que falar ao microfone para uma plateia de professores ansiosos por falas que pudessem agregar conhecimento e metodologias em suas aulas. Foi a conquista de uma liberdade de pensamento que conduziu à ação, que me permitiu o conhecimento do que é e do que pode ser a educação; isso deu início a minha emancipação e à possibilidade de contribuir para a emancipação dos alunos com os quais eu compartilhar conhecimento, que eu compartilhar minha vida.".

Uma participante, membro do GEFOPI e egressa do Curso de Pedagogia do Câmpus Luziânia da UEG falou de sua formação continuada ao afirmar que "Participei da mesa redonda, este momento me permitiu discutir e refletir sobre a formação e atuação docente tendo em vista minha práxis enquanto profissional da educação formado em área específica e em formação em pedagogia.".

Aos componentes do GEFOPI, foi questionado tanto nas fichas quanto em reuniões após os eventos, suas avaliações sobre a gestão de espaço, de atividades e de pessoas; que contribuições o evento tem proporcionado para sua formação e uma dos componentes respondeu que "possibilitou experiência e prática nos aspectos acadêmico e humano. [...] aprendizado fundamental para professores em formação inicial e continuada. A atenção aos detalhes da organização: ornamentação, disposição do data show, [...] garantiu o bom andamento do evento". Outra resposta foi que "As atividades foram muito bem direcionadas e possibilitaram o encontro e diálogo entre profissionais da educação, o que foi fantástico. Todavia percebo que o tempo para o debate em geral sobre a proposta apresentada e diálogo [...] poderia ser maior, permitindo uma ampla discussão e construção de saberes.". Para outro componente: "Pude perceber que esse tipo de trabalho em equipe é mais do que reuniões para organizar o evento; mais do que estabelecer a logística de divulgação e de realização. É preciso amor pelo que se propõe fazer; acreditar no resultado que se pretende alcançar, pois sem esse olhar qualquer proposta de formação de professores pode ficar perfeita na forma, mas não será suficiente para alcançar o conteúdo de nenhum dos sujeitos envolvidos no processo. É uma formação inócua.".

Diante das respostas muito objetivas dos participantes da comunidade externa nas três primeiras edições do ENFORMA, o que dificultou a avaliação quanto ao que foi agregado à formação por meio do evento, as fichas de avaliação serão reestruturadas para que não sejam elencados somente os pontos positivos e negativos, mas para que seja possível a exposição sobre a formação continuada, principalmente aos que participarem de mais de um 
evento. Também para termos um resultado teórica e metodologicamente mais apurado e confiável, foi proposto e aprovado pela Pró-reitoria de Pesquisa da Universidade Estadual de Goiás uma pesquisa intitulada "O ENFORMA - Encontro de formação de professores como possibilidade de formação continuada e inicial" para que possam ser pesquisadas as contribuições do ENFORMA para a formação de cada partícipe, seja ele membro do GEFOPI ou da comunidade externa.

No geral, a avaliação que temos do ENFORMA é muito positiva e muito nos emociona ter o reconhecimento do público quanto ao nosso trabalho, pois um participante frisou que "Gostaria de parabenizar os idealizadores do encontro por estarem trazendo para os estudantes, pesquisadores e para a comunidade em geral esse espaço para discussão de pontos relevantes da educação.". Também nos emocionamos com falas como essa "Gostaria que mais pessoas pudessem ser contempladas com tudo isso que o ENFORMA pôde me proporcionar em termos de conhecimento e liberdade de pensamento e ação. Que possamos continuar a receber em nosso grupo todos os que buscarem conhecer e contribuir coma formação de alguém que precisa dessa luz para tirar dos olhos a cegueira da ignorância. E que venham as próximas edições do ENFORMA.”.

\section{CONSIDERAÇÕES}

As universidades enquanto instituições formadoras de professores, aqui destacam-se as universidades públicas, devem visar uma formação docente para a emancipação humana e para isso a práxis é indispensável. Uma forma de se alcançar essa práxis é no trabalho concreto e intelectual, no processo de discussão de didática e prática de ensino, nos vários níveis e modalidades educacionais. Assim, a formação de professores precisa ser refletida como um processo constituído por conhecimentos teóricos e práticas pedagógicas - isto é, práxis - ambos fundamentados epistemologicamente, tanto na Educação Básica quanto no Ensino Superior.

Uma ação emancipadora que só pode ser construída por meio da atividade analisada e modificada na forma e no conteúdo. Dessa forma, as pesquisas consolidam a base do conhecimento, cientificam as conquistas ao longo dos tempos e fortalecem as reflexões acerca do ser e estar no mundo para o desenvolvimento da criticidade diante do que está posto para o que pode ser 
mudado. Destarte, o diálogo sobre as pesquisas, ações extensionistas e as experiências exitosas precisam ser socializadas.

A extensão universitária, proclamada em documentos legais, como uma das bases do tripé universitário e elemento da indissociabilidade com a pesquisa e o ensino, precisa ser compreendida para então ser planejada e executada. A discussão das concepções da extensão universitária pode vir a influenciar a formação docente, ao passo que as instituições compreendem que suas funções serão alcançadas por meios das atividades do ensino, da pesquisa e da extensão e, principalmente, quando a instituição formadora compreende que a extensão universitária pode ser um dos caminhos para viabilizar as transformações sociais, mas afastando suas atividades extensionistas da concepção assistencialista e mercantilista.

Esse é o trabalho do GEFOPI para a conscientização da importância e necessidade da articulação ensino, pesquisa e extensão para a formação na universidade, em especial para a formação de professores, olhando a prática de ensino nesse processo. Assim, as transformações sociais poderão acontecer com o trabalho concreto de professores formados de maneira crítica e emancipadora.

Dessa forma, compreendemos que o projeto de extensão ENFORMA - que partiu de uma demanda real da rede municipal de ensino de Luziânia; buscou parceria com a Secretaria Municipal de Educação; modificou-se e adequou-se para atender às solicitações e sugestões de participantes; tornou-se um projeto de pesquisa para dimensionar e colaborar para a reestruturação do próprio encontro, e divulgar as contribuições para a formação inicial e continuada de acadêmicos e professores - tem alcançado os objetivos de sua criação enquanto possibilitador de aprendizagens, criticidade e quiçá emancipação, bem como oportunizador de variadas práticas de ensino, demonstrando a seus partícipes que o professor que não pesquisa não tem o que ensinar, conforme esclarece Demo (2006). Acima de tudo, o ENFORMA tem mostrado que esse processo de estudar, pesquisar e ensinar amadurece o professor, no sentido de ser um professor emancipador pela unidade teoria e prática lá no chão da escola.

\section{REFERÊNCIAS}

DEMO, Pedro. PESQUISA: Princípio científico e educativo. 12 ed. São Paulo: Cortez, 2006. 
GEFOPI, Grupo de Estudos em Formação de Professores e Interdisciplinaridade. GEFOPI Andréa. Facebook, 2017.

JEZINE, Edineide Mesquita. As Práticas Curriculares e a Extensão Universitária.

Anais do $2^{\circ}$ Congresso Brasileiro de Extensão Universitária Belo Horizonte, 12 a 15 de setembro de 2004. In: https://www.ufmg.br/congrext/Gestao/Gestao12.pdf

MOREIRA, Antonio Flavio Barbosa. Currículo e formação de professores: notas para discussão. In: LIBÂNEO, José Carlos; SUANNO, Marilza Vanessa Rosa; LIMONTA, Sandra Valéria (Org.). Qualidade da escola pública: políticas educacionais, didática e formação de professores. Goiânia: Ceped Publicações; Gráfica e Editora América; Kelps, 2013. p. 107-130.

REIS, Renato Hilário dos. Extensão Universitária: conceituação e práxis. In: I Fórum de Extensão da UDESC. Florianópolis - SC: UDESC, 1993.

REIS, Renato Hilário dos. Histórico, Tipologias e Proposições sobre a Extensão Universitária no Brasil. Cadernos UnB Extensão: A universidade construindo saber e cidadania. Brasília, 1996. In: http://periodicos.unb.br/index.php/linhascriticas/article/ download/6094/5042.

SÍVERES, Luiz. O Princípio Da Aprendizagem Na Extensão Universitária. In: SÍVERES, Luiz (Org.) A extensão universitária como princípio de aprendizagem. Brasília: Liber. 2013. In: http://unesdoc.unesco.org/images/0023/002320/232083por.pdf 